\title{
O JOGO DOS SENTIDOS: ESTRUTURAS DUPLAS DA ARTE E A CATEGORIA DO SENTIDO EM VIGOTSKI
}

\author{
THE INTERPLAY OF SENSES: ART DUAL STRUCTURES AND \\ THE CATEGORY OF SENSE IN VYGOTSKY
}

\author{
Priscila Nascimento Marques ${ }^{1, \star}$
}

RESUMO: O artigo rastreia as ocorrências do termo "sentido" em diferentes textos vigotskianos sobre arte, bem como no capítulo "Pensamento e palavra", de A Construção do Pensamento e da Linguagem. Diferentes formulações e uma terminologia pouco precisa fornecem indícios da distinção que o autor faria em sua obra final entre significado e sentido.

Palavras-chave: Vigotski. Psicologia da arte. Sentido. Significado.

ABSTRACT: This paper traces the term "sense" in several Vygotskian texts about art as well as in "Thought and word", chapter of Thinking and Speech. Various formulations and an imprecise terminology offer traces of the distinction that the author would crystalize in his final work between meaning and sense.

Keywords: Vygotsky. Psychology of art. Sense. Meaning.

1.Universidade de São Paulo - Faculdade de Filosofia, Letras e Ciências Humanas - São Paulo (SP), Brasil.

*Autora correspondente: prinmarques@alumni.usp.br

Dossiê organizado por: Gisele Toassa e Ana Luiza Bustamante Smolka

Pós-doutorado financiado pela Fapesp (Processo n. 2015/17.830-1). 


\section{Introdução}

O prefácio de L S Vigotski (VIGOTSKI; LEONTIEV, 2020) ao livro O Desenvolvimento da Memória, de A N Leontiev, cuja primeira tradução em português aparece neste volume dos Cadernos Cedes, mostra o autor na fase final de sua carreira, em plena atividade de construção e revisão crítica das bases de uma psicologia histórico-cultural. Dois anos após a finalização do livro, Vigotski revisita o estudo com apontamentos agudos, que indicam superação do esquematismo das tendências idealistas e deterministas na psicologia. A origem desse impulso pode ser verificada desde muito cedo em sua obra. Tomaremos aqui o caso do conceito de "sentido" em sua evolução na obra vigotskiana sobre arte.

No campo da psicologia da arte, a contribuição vigotskiana aparece de forma mais madura na obra de 1925, em cujo prefácio o autor revela que aquele era o resultado de trabalhos anteriores, entre os quais "vários artigos e notas de revistas" (VIGOTSKI, 2001a, p. 1). Trata-se de um amplo corpus de resenhas teatrais e outros textos publicados entre 1922 e $1923 \mathrm{em}$ Gomel, onde o autor viveu antes de iniciar seus estudos universitários em Moscou e para onde retornou após sua conclusão. $\mathrm{O}$ estudo desse material revela o laboratório do que mais tarde aparecerá sob a denominação de método objetivamente analítico (VIGOTSKI, 2001a, p. 25) ${ }^{1}$.

As resenhas, contudo, não visavam a um objetivo teórico; eram, antes, exercícios práticos de análise das encenações (ou seja, do trabalho do diretor e dos atores). Já no "período de Gomel", Vigotski aponta para o caráter social e pedagógico da arte e da crítica de arte, e revela uma compreensão do objeto artístico como um complexo organizado de estímulos que devem ser reconstruídos pelo receptor mediante trabalho ativo da percepção e da imaginação.

O presente artigo pretende localizar a noção de sentido (smysl) em diferentes momentos da obra do autor, em suas variações, nuanças e contextos. Ocorrências do termo foram encontradas e cotejadas nos seguintes textos: A Tragédia de Hamlet (1999), resenhas teatrais do período de Gomel, a apresentação do livro com obras do artista plástico Bykhóvski e o último capítulo de A Construção do Pensamento e da Linguagem (VIGOTSKI, 2001b). A presente análise tem por objetivo: a) detectar o conceito de sentido em sua elaboração como estrutura dupla nos textos sobre arte; b) identificar as transformações do conceito no corpus selecionado; c) esboçar a relação entre o conceito de sentido nos textos sobre arte e como categoria da psicologia geral vigotskiana.

\section{A Tragédia de Hamlet, Príncipe da Dinamarca}

O ensaio sobre a tragédia shakespeariana é um texto singular, que teve pouca atenção de estudiosos ocidentais, talvez por dificuldades de reconciliar o tom simbolista e metafísico com a psicologia histórico-cultural, de base materialista dialética.

A interpretação vigotskiana da tragédia se baseia na ideia de que Hamlet vive no limiar entre dois mundos: um material, visível e um além-mundo, invisível, que é determinado pelo primeiro. Essa é a primeira estrutura dupla identificada por Vigotski na arte. Ela, por sua vez, determina um sentido também duplo: o primeiro deriva da narração exterior dos fatos; o segundo sentido (vtoroy smysl) “consiste na própria tragédia [...] existe nela, mesmo sendo irracional [...] Esse 'sentido' é dado na própria tragédia, ou melhor, existe nela, no seu tom, nas suas palavras” (VIGOTSKI, 1999, p. 8). Para Vigotski, o silêncio, o drama invisível, isto é, o segundo sentido, subjacente, não é diretamente acessível ao receptor. Ele pode apenas ser sentido por meio de vestígios fornecidos pelo drama, por 
meio de suas "palavras, palavras, palavras". Assim, o segundo sentido só pode ser vivenciado pelo crítico, mas não explicado até o fim. A função do crítico não é resolver o enigma, mas apontar para ele e aceitá-lo como tal.

Isso é tudo. Só isso. É preciso tomar o mistério como mistério. Vaticinar é coisa de profanos. O invisível não é absolutamente sinônimo de inatingível: dispõe de outros acessos para a alma. O inexprimível, o irracional são percebidos por outros dispositivos sensíveis da alma até hoje não decifrados. O misterioso não se atinge pelo vaticínio, mas pela sensação, pelo vivenciamento [perejivânie] do misterioso. O "resto" se atinge no silêncio da tragédia. É nisso que consiste a arte do poeta trágico (VIGOTSKI, 1999, p. 12, grifos do autor).

O pathos religioso em seu comentário sobre a tragédia é flagrante. O segundo sentido é da ordem do místico e do sobrenatural; é tema da metafísica e exige uma atitude religiosa. Sendo o ensaio uma peça de crítica literária, o autor pode apenas entrever, aludir, insinuar essa camada mais profunda. A tragédia se estende em dois âmbitos: é a um tempo arte e religião. O segundo sentido é a instância superior que determina as ações mundanas que parecem imotivadas. O Vigotski de 1915 aproxima experiência estética e experiência religiosa - esta derivada das ideias de James (1999) - e afirma que o mistério engendrado pela arte deve ser reconhecido e aceito como tal. $\mathrm{O}$ crítico pode apenas vislumbrar a possibilidade de ouvir o não dito, desvelar o inexprimível.

\section{Resenhas Teatrais}

O artigo “Turnê de E V Guéltser” foi a primeira de uma longa série de resenhas que Vigotski publicaria no periódico gomeliano Nach Ponediélnik (posteriormente renomeado Poliésskaia Pravda), entre 1922 e 1923. O tom laudatório à bailarina e à arte do balé marca o texto. Vigotski o define o balé com uma arte que não é fácil tampouco popular, mas "uma das maiores criações do espírito artístico [...] por sua grande profundidade" (2015a, p. 264). Em sua ode à dança clássica, o autor destaca seu caráter não figurativo e artificial, características opostas às da chamada dança natural, em voga na época:

[A dança clássica] é indefinida. Nada expressa, nada relata, tampouco exprime alguma experiência psicológica concreta e determinada. A dança clássica é tão indiferente à reprodução do movimento natural e à expressão do pequeno sentido anímico quanto a música o é em relação à onomatopeia; assim como a música, ela constrói, de modo autônomo, com a plástica viva das formas artificiais animadas pelo ritmo, seu mundo particular de grande sentido, não anímico, mas espiritual. Assim como a música, a dança abala a alma humana por meio de uma construção artificial que, também como a música, não pode ser traduzida para nenhuma outra língua. Todos os procedimentos de sua técnica são calculados justamente para cortar de imediato todas as relações e associações existentes entre o movimento e a psicologia elementar. A bailarina fica na ponta dos pés (com os dedos esticados) e se abstrai do movimento natural. Da mesma forma que a pessoa que começa a se expressar em versos ou em canção se abstrai da fala natural (VIGOTSKI, 2015a, p. 264-265, grifos do autor). 
Aqui, novamente, a categoria do sentido é dupla; novamente a distinção tem caráter hierárquico. Enquanto, em Hamlet, a distinção dava-se entre primeiro e segundo sentido, hierarquizados de modo ascendente, na resenha sobre Guéltser a hierarquia é ainda mais explícita: pequeno e grande sentido. E mais: anímico versus espiritual. Com tal distinção, Vigotski enfatiza o caráter autônomo da arte em relação à realidade concreta e à psicologia individual, ou, ao menos, a capacidade que ela revela de superar ambos, de modo que, por meio da arte, seria possível atingir um nível superior no processo de produção de sentido.

As noções de alma (duchá) e espírito $(d u k h)^{2}$ remetem à filosofia de S. L. Frank (SÓBKIN; MAZÁNOVA, 2014). Em O Espírito do Homem, Frank (s./d.) considera que a vida espiritual é maior do que o fato psicológico e indica uma relação entre vida interior e experiência estética. Para o filósofo, o mundo interior não coincide com o exterior e sua expressão material, mas envolve a noção de "vsetcheloviétchnost" (humano universal), de modo que a arte e a religião servem para absorver e expressar tais potenciais que, de outro modo, permaneceriam desperdiçados.

No ano seguinte, em “Turnês de Utiôssov e Foregger”, Vigotski (2015b, p. 273) define a dança clássica como "linguagem pura das formas coreográficas, que não expressa nenhum sentido concreto". Aqui, o autor revela sua concepção de arte como sistema semiótico abstrato e convencional (KUBÁSSOV, 2015). Com a distinção entre as esferas anímica e espiritual na produção de sentido, para Vigotski, os sentidos produzidos pela arte superam o estreito círculo da psicologia individual e das emoções elementares. Nessa passagem da resenha, tem-se o embrião de ideia que apareceria mais bem-elaborada em Psicologia da Arte: as emoções produzidas pela reação estética são "emoções inteligentes". Sua terminologia, contudo, ainda traz o verniz do simbolismo, ou seja, está no meio caminho entre o ambiente cultural da Era de Prata - com seu misticismo - e a noção de arte como técnica social (supraindividual, portanto) dos sentimentos.

A dança, do mesmo modo que a literatura, deve libertar-se o máximo possível da linguagem cotidiana ${ }^{3}$, e o balé é o gênero que melhor supera a pragmática usual do movimento.

Ao resenhar peças teatrais, Vigotski com frequência comenta os aspectos não verbais: gestos, postura, voz etc. Em uma resenha de 1922, observa que os gestos cênicos não devem servir para meramente ilustrar as palavras, mas antecipá-las. O gesto "não ilustra o sentido (smysl) lógico e material, mas comunica ao texto o sentido psicológico e espiritual (dukhóvnyi)" (VIGOTSKI, 2015c, p. 238).

Numa resenha de 1923 sobre a turnê da companhia Tocha Vermelha, Vigotski trata não apenas da dança e do teatro, mas afirma que o último tem origem na primeira:

\begin{abstract}
Mas o drama nasceu da dança, e os movimentos humanos formam uma melodia, como sons de uma escala, e criam uma grande música, repleta de enormes sentidos [ogrómnie smysly]. Agora, o drama retorna à dança. A beleza plástica e a expressividade do movimento do ator separadamente e de seu grupo, a música dos gestos adquire um significado não apenas auxiliar, mas de domínio de si. Tudo isso pode ser resumido em uma frase: o teatro não é uma cópia da vida ou da história, pois a palavra, o movimento, o cenário - todos os seus elementos - se emanciparam em relação ao estreito sentido [smysl] psicológico, cotidiano e ligado à vida; eles se transformaram artisticamente e passaram a ser material (2015d, p. 377).
\end{abstract}

Verifica-se que, nesse período, a terminologia empregada por Vigotski para descrever o nível de elaboração do sentido na arte varia e se revela vaga e imprecisa. Na resenha sobre Guéltser, tem-se 
anímico versus espiritual (duchévnyi vs. dukhóvnyi); mais tarde, ainda em 1922, o autor equipara os termos psicológico e espiritual (psikhologuitcheski i dukhóvnyi) e os contrapõe aos termos lógico e objetivo. Em 1923, evita empregar o termo "espiritual” e recorre à expressão "enormes sentidos" em oposição ao sentido estreito, psicológico e comum. Apesar dessas inconsistências, há um denominador comum: a capacidade da arte de emancipar-se da vida e de alcançar sentidos mais amplos e profundos.

\section{A Arte Gráfica de Bykhóvski}

O texto "A arte gráfica de Bykhóvski” aparece como apresentação num volume de obras do artista publicado em 1926. Trata-se de uma peça altamente singular no repertório vigotskiano, pois o autor, que havia se dedicado a escrever sobre literatura e teatro, raramente escrevia sobre outras formas de arte, sendo esta sua única produção no campo das artes visuais. O tipo de arte pode ter variado, mas o tom permanece indefectivelmente vigotskiano desde o princípio.

A dualidade é o primeiro aspecto observado pelo autor: "a chave para a compreensão dos desenhos de Bykhóvski está na duplicidade de sua interpretação e percepção espacial” (VIGOTSKI, 2015e, p. 281). Sua argumentação se baseia nas ideias de Broder Christiansen, particularmente em sua distinção entre desenho e pintura, e as diferentes reações que ambos provocam no receptor. Enquanto a pintura promove o espaço imaginário em detrimento do aspecto plano da tela (seu espaço real), a arte gráfica reforça igualmente os planos bidimensional e tridimensional. Vigotski fala de uma linguagem da linha, revelando novamente uma compreensão da arte em termos semióticos. Em seguida, resume sua interpretação sobre a originalidade da obra daquele artista plástico:

Como já foi dito, nisto está a chave para os desenhos de Bykhóvski. Em cada um de seus trabalhos a linha desempenha duas funções espaciais e estilísticas totalmente diferentes. As linhas descrevem alguma coisa, mas também expressam outra. Elas carregam o tema material do desenho, mas também carregam sua resolução, sua catarse gráfica particular. O desenho de Bykhóvski é construído em dois planos especiais e estilísticos: um deles é o tridimensional-material-representativo, o outro é o plano-abstrato-rítmico. Este jogo dos dois sentidos do seu desenho, esta superação e dissolução em um lirismo das linhas, independente de qualquer tema material, compõe o principal traço de sua obra (VIGOTSKI, 2015e, p. 281-282).

Essa passagem não indica uma hierarquia entre os dois níveis mencionados, tampouco descreve os sentidos que derivariam deles. Assim como no ensaio sobre Hamlet, a contradição é identificada na estrutura formal da obra e na natureza específica daquele tipo de arte. A indicação de contradições na construção artística (especialmente a oposição entre material e forma), as quais, por sua vez, despertam emoções também de caráter contraditório, é uma constante no pensamento vigotskiano sobre arte, que revela as profundas raízes de seu pensamento dialético.

No caso de Bykhóvski, a duplicidade do princípio construtivo leva a uma percepção dupla da obra: o olhar inicialmente decodifica/reconhece o conteúdo da obra; em seguida, o observador atento percebe como o conteúdo é realizado. No retrato de Liachkó, por exemplo, o adereço pode ser visto como um chapéu retangular. Por outro lado, sua representação em ziguezagues e linhas quebradas transformam-no em uma imagem complexa e incomum. Um novo sentido é comunicado, o qual supera a materialidade e a concretude, revelando um retrato realizado pela linguagem das fábricas, 
no espírito do construtivismo. Outro exemplo é o autorretrato do artista, no qual o adereço da cabeça parece, a um tempo, chapéu e halo. Bykhóvski apresenta um círculo rígido, que serve como moldura estilizada para o rosto, aliando a técnica dos ícones e a linguagem artística da vanguarda. Tanto o chapéu quanto o rosto são reais e reconhecíveis, mas, na composição, são elevados a outro nível de realidade, no qual "todo o sentido da melodia da linha é comunicado ao rosto e o eleva a uma altura inacessível ao realismo” (VIGOTSKI, 2015e, p. 283).

\section{Psicologia da Arte}

Após apresentar uma série de análises de como a arte se organiza em dois planos contraditórios, Vigotski formula sua compreensão dos efeitos desse procedimento em termos de leis psicológicas, sendo a catarse a primeira delas:

Se o artista extrai da pedra essa ousadia e essa ternura, ele se sujeita à mesma lei que o obriga a projetar para o alto a pedra que é atraída para o chão e criar na catedral gótica a impressão de uma flecha que voa para o alto. Essa lei se chama catarse, e foi precisamente ela, e não outra, que levou o antigo mestre a colocar na catedral Nossa Senhora de Paris imagens terríveis e deformadas de monstros e esplêndidas quimeras, sem as quais a catedral teria sido impossível (VIGÓTSKI, 2001a, p. 301).

Em cada ensaio crítico apresentado em Psicologia da Arte, as obras literárias são analisadas à luz de dualidades e contradições. As fábulas, por exemplo, são marcadas pela oposição entre a tarefa moral -e mais evidente - e a tarefa poética, intersticial. Ao fundo, o poeta destila seu "suave veneno", que intensifica e marca o efeito poético da narrativa:

[...] descobrimos que o veneno sutil constitui provavelmente a verdadeira natureza da poesia de Krilov, que a fabula é o germe da lírica, da epopeia e do drama, e, pela força da poesia nela contida, leva-nos a reagir pelo sentimento à ação que ela desenvolve. Descobrimos, por último, que a contradição emocional e a sua solução no curto-circuito dos sentimentos opostos constituem a verdadeira natureza da nossa reação psicológica diante da fábula (VIGÓTSKI, 2001a, p. 175).

Ao analisar a novela Leve Alento, de Ivan Búnin, Vigotski examina as mudanças feitas pelo autor na ordem cronológica dos eventos, de modo que o efeito produzido pela "fábula (fabula, os eventos narrados)" contrasta com aquele derivado do siujét (a maneira como os eventos são narrados). Esse procedimento é descrito por meio de uma imagem bíblica, o milagre da transformação de água em vinho: "As palavras de uma narração ou de um verso implicam o seu sentido simples, a sua água, enquanto a composição, ao criar sobre essas palavras, acima delas, um novo sentido, dispõe tudo isso em um plano bem diferente e transforma água em vinho" (VIGÓTSKI, 2001a, p. 191-192). A oposição se dá aqui entre o sentido simples e novo, água e vinho. A palavra crua é portadora de um significado original, que se vê transformado pelo artista por meio da composição. Nesse processo, um novo sentido é criado, um sentido que surge sobre o significado primário e o supera.

Dez anos após a escrita do ensaio sobre Hamlet, uma versão significativamente alterada é apresentada em Psicologia da Arte. Embora muitos argumentos se mantenham, verifica-se o abandono 
da crítica do leitor em favor do método que o autor denomina objetivamente analítico. A duplicidade estrutural da tragédia ainda é fundamental para a análise, mas nenhuma palavra é dita sobre o "segundo sentido", onipresente no ensaio de 1915. Aqui, a argumentação considera que, apesar de a tragédia indicar uma sequência lógica de ações (Hamlet descobre a armação e vinga o pai), constantemente dela se desvia. Continua presente a análise dos procedimentos formais e da reação que deles deriva; já o caráter mítico - marcante na primeira versão - é negado: "Daqui, entretanto, não se conclui que o efeito da arte tenha nada de misterioso, de místico, ou que sua explicação exija quaisquer novos conceitos e leis além daqueles já estabelecidos pelo psicólogo ao analisar o comportamento comum” (VIGÓTSKI, 2001a, p. 320).

\section{Pensamento e Palavra}

Embora o termo "sentido" apareça nos trabalhos citados anteriormente, é apenas em Pensamento e Linguagem que essa noção recebe elaboração teórica. Para definir o conceito, Vigotski recorre às ideias de Paulhan (1928), especificamente à distinção feita por esse autor entre significado e sentido. O sentido de uma palavra é uma formação dinâmica e fluida, que engloba todos os fatos psicológicos despertados por ela. Ele se modifica de acordo com um número infinito de variáveis (p. ex., contexto, pensamento, emoções), ao passo que o significado (znatchénie) é uma formação mais estável: apenas um dos inúmeros conteúdos que uma palavra pode adquirir, uma de suas camadas. A origem das ideias de Vigotski sobre a produção de sentido e o papel do indivíduo (espírito, nas palavras de Paulhan) na organização dos fatos psicológicos suscitados pela palavra está em Paulhan:

O sentido de uma palavra, em sua definição mais ampla, é o conjunto de fatos psicológicos que essa palavra desperta no espírito, e que a reação do espírito não rejeita, mas recebe e organiza. Esses fatos são, antes de tudo, tendências, tendência a pensar, a sentir, a agir, tendências abstratas, hábitos, mas também imagens, ideias e emoções. A combinação delas constitui a atitude mental, uma síntese mais ou menos fechada, ou numerosas sínteses mais ou menos unidas (1928, p. 289).

Para ilustrar a diferença entre sentido e significado, Vigotski retoma a análise da fábula "A cigarra e a formiga", apresentada inicialmente em Psicologia da Arte. Retoma, mais precisamente, o uso do verbo "dançar" no final da história, cujo significado literal é confrontado no texto com uma segunda camada que o amplia, fazendo-o descrever, ao mesmo tempo, "divertir-se" e "morrer":

Esse enriquecimento das palavras que o sentido lhes confere a partir do contexto é a lei fundamental da dinâmica do significado das palavras. A palavra incorpora, absorve de todo o contexto com que está entrelaçada os conteúdos intelectuais e afetivos e começa a significar mais e menos do que contém o seu significado quando a tomamos isoladamente e fora do contexto: mais, porque o círculo de seus significados se amplia, adquirindo adicionalmente toda uma variedade de zonas preenchidas por um novo conteúdo; menos, porque o significado abstrato da palavra se limita e se restringe àquilo que ela significa apenas em um determinado contexto (VIGÓTSKI, 2001b, p. 465-466).

Em 1925, Vigotski já havia identificado a ambiguidade da palavra no desfecho da fábula. Para os fins de uma análise da reação estética, ele explora então os efeitos causados pela justaposição do 
significado e do sentido, sendo que cada um evoca um tipo de emoção. Em Pensamento e Linguagem, o aspecto emocional se torna parte da compreensão do processo de produção de sentido. O pensamento não coincide com sua expressão verbal, e não é apenas determinado cognitivamente.

Não é coincidência que a arte se faça presente na última obra psicológica de Vigotski. Nela, ele elabora uma ideia que já se pode entrever no texto de 1925: "não se pode resolver com precisão a questão do sentido e da estrutura de toda a forma artística sem ter nenhuma ideia definida no campo da psicologia da arte" (VIGOTSKI, 2001a, p. 72). Se em Pensamento e Linguagem, os mecanismos subjacentes do pensamento, da simbolização e da produção de sentido são desvelados, em Psicologia da Arte, Vigotski mostra como a arte, como sistema semiótico complexo, concentra processos biológicos e sociais que harmonizam ${ }^{4} \mathrm{o}$ indivíduo e a sociedade e, enfim, funciona como instrumento da produção do novo homem.

\section{Considerações Finais}

A partir dos trechos analisados, observa-se como o pensamento de Vigotski opera em termos de noções que se contrapõem, coincidem e se complementam. De modo geral, pode-se dizer que aquilo que Vigotski chama inicialmente de "primeiro sentido", anímico, psicológico, lógico ou representacional, aproxima-se do que, em sua obra final, seria designado sob o conceito de significado (znatchênie), ao passo que o "segundo sentido", espiritual, psicológico, abstrato e enorme, encontram-se no campo da noção de sentido propriamente (smysl). Contudo, tais termos não podem ser simplesmente tomados como equivalentes plenos, sob risco de se desconsiderarem nuanças, alterações, interlocutores, referências e contextos em que cada obra surgiu.

A noção de experiência religiosa/mística dá lugar à experiência/reação estética. O emprego do adjetivo "espiritual" para qualificar o sentido alcançado pela arte perde força e, por fim, desaparece. O que permanece é a ideia de emancipação, superação da realidade, que é vista como a principal tarefa da arte. Em termos metodológicos, a percepção individual e subjetiva dá espaço à análise minuciosa, objetiva, baseada na identificação de procedimentos artísticos, e à dedução das leis do impacto emocional produzido por esses procedimentos no receptor. Aspectos sociais e históricos, pouco frequentes no primeiro ensaio, tornam-se cada vez mais relevantes: a experiência estética é vista como um tipo de experiência que traz o social para o indivíduo: "a arte é o social em nós" (VIGOTSKI, 2001a, p. 315).

Ademais, a atitude do crítico (e, posteriormente, do psicólogo) se move da passividade para a atividade. Seu objeto se desloca do âmbito do intangível para o âmbito do concreto e do alcançável. Enquanto, no ensaio sobre Hamlet, a tarefa do crítico consistia em dar certa direção à percepção da tragédia - um objetivo em si mesmo, sem implicações práticas -, em Psicologia da Arte, o crítico é socialmente engajado: "dá um notório salto do campo da arte para o campo da vida social que lhe é estranho, mas apenas para direcionar as forças desencadeadas pela arte no curso socialmente necessário" (VIGOTSKI, 2001a, p. 322).

A categoria de sentido, que aparece, no primeiro ensaio, ligada a uma aura de mistério e religião, torna-se o degrau mais alto de uma escada, que podemos e devemos subir se quisermos avançar social e individualmente. Se a arte aparece como esfinge, o jovem Vigotski de 1915 permitia-se ser devorado, reconhecendo a derrota, ainda que lutasse. Dez anos mais tarde, imbuído das possibilidades de transformação social trazidas pela Revolução de Outubro, o enigma deve ser decifrado.

Retomando o texto do prefácio ao livro O Desenvolvimento da Memória, verifica-se que Vigotski insiste em que não se deva igualar as formas superiores e inferiores dos processos psicológicos, 
tampouco negligenciar o papel do aspecto semântico (ou seja, dos significados). Isto é, não se pode "esquecer o desenvolvimento dos significados e, portanto, reduzir de forma substancialmente mecanicista as formas superiores dos processos mediados às formas inferiores desses mesmos processos" (VIGOTSKI; LEONTIEV, 2020, p. 120).

O objetivo do artigo foi chamar atenção para o fato de que, independentemente de estar sustentado em uma acepção conceitual clara, a noção de sentido já se faz presente de forma embrionária nos escritos iniciais. Mais do que isso, tais escritos já apontam para um caráter dual. Tal dualidade se expressa, nos primeiros escritos, em termos variáveis (espiritual, anímico, psicológico etc.), conforme o ambiente intelectual e os interlocutores do autor em cada momento de sua obra (inicialmente o simbolismo, depois, paulatinamente, a incorporação de um vocabulário psicológico e, por fim, a incorporação da terminologia de Paulhan). Dessa maneira, o objetivo do artigo foi rastrear tais ocorrências e verificar nelas continuidades (no teor de seu pensamento) e descontinuidades (conforme as variações de fontes e interlocutores).

Os escritos iniciais revelam que a arte é um campo de produção de sentidos novos/superiores e é, portanto, uma dimensão da liberdade humana (ZAVERSHNEVA, 2016). A figura do poeta criador de sentidos por excelência - surge com grande destaque. Nessa perspectiva, em que arte, criação e liberdade se encontram, ressoam as palavras da poetisa Olga Sedakova (2001) sobre Vigotski: "Na criação artística, no trabalho com a vida livre da forma, segundo Vigotski, o psiquismo não luta contra o próprio passado [...], ele constrói seu futuro, seu permanente nascimento."

\section{Notas}

1. Entre os intérpretes e comentadores desse material recém-descoberto, estão, por exemplo Sóbkin (2016), Marques (2015), van der Veer (2015), Maltsev (2000).

2. No excerto citado, encontram-se as formas adjetivadas desses substantivos: dukhóvnyi e duchévnyi, vertidos para o português como "espiritual" e "anímico", respectivamente.

3. Conforme distinção entre linguagens poética e prática dos Formalistas Russos (ver POMORSKA, 1972).

4. Como observa Hansen-Löve (2001), diferentemente de Freud, que vê uma oposição trágica entre a busca pela satisfação do prazer e a adaptação à realidade, o que gera toda ordem de desarranjos psicológicos, Vigotski parte do princípio de uma compreensão positiva da harmonização.

\section{REFERÊNCIAS}

CHRISTIANSEN, B. Philosophie der Kunst. Hanau: Clauss \& Feddersen,1909.

FRANK, S. L. Duchá tcheloviéka, [s/d]. Disponível em: <https://azbyka.ru/otechnik/Semen_Frank/ dusha-cheloveka-opyt-vvedenija-v-filosofskuyu-psihologiyu/\#0_11> Acesso em: 01 maio 2019.

HANSEN-LÖVE, A. Russki Formalizm. Moskva: Iazyk Russkoi Kultury, 2001. 
JAMES, W. The varieties of the religious experience: a study in human nature. New York: The Modern Library, 1999.

KUBÁSSOV, A. V. Formirovanie kulturno-istoricheskoi psikhologuii v teatralnykh retsenziiakh L. S. Vygotskogo, Pedagoguicheskoe Obrazovanie v Rossi, n. 8, p. 77-82, 2015.

MALTSEV, V. V. Teatr 1920-kh godov v otsenke L. S. Vygotskogo. In: KOVALENKO, G. I. Russki avangard 1910-kh - 1920-kh godov i teatr. Saint Petersburg: Dmitri Bulanin, 2000, p. 208-221.

MARQUES, P. N. O Vygótski incógnito: Escritos sobre arte (1915-1926). 2015. Tese (Doutorado em Literatura e Cultura Russa), FFLCH - Universidade de São Paulo, São Paulo, 2015.

PAUlhan, F. “Qu'est-ce que le sens des mots?”, Journal de Psychologie Normale et Pathologique, v. 25, n. 4-5, p. 289-329, 1928.

POMORSKA, K. Formalismo e futurismo. São Paulo: Perspectiva, 1972.

SEDAKOVA, O. “Seiatel otchei”. Slovo o L. S. Vygotskom. Proza. Moscou: Em Ef Kiu/Tu Print, 2001. Disponível em: <http://www.olgasedakova.com/Poetica/1170>. Acesso em: 9 maio 2019.

SÓBKIN, V. S. Stanovliénie L. S. Vygotskogo kak teatralnogo Kritika: Pervie opyty. Razvitie Lichnosti, n. 4 , p. 37-66, 2016.

SÓBKIN, V. S.; MAZÁNOVA, V. S. Opyt kommentariev k odnoi teatralnoi retsenzii L. S. Vygotskogo, National Psychological Journal, Moscou, v. 1, n. 13, p. 35-46, 2014.

VAN DER VEER, R. Vygotsky, the theater critic: 1922-3. History of the Human Sciences, v. 28, n. 2,2015 .

VIGOTSKI, L. S. A tragédia de Hamlet, príncipe da Dinamarca. Trad. Paulo Bezerra. São Paulo: Martins Fontes, 1999.

VIGOTSKI, L. S. Psicologia da arte. Trad. Paulo Bezerra. São Paulo: Martins Fontes, 2001 a.

VIGOTSKI, L. S. A construção do pensamento e da linguagem. São Paulo: Martins Fontes, 2001 b.

VIGOTSKI, L. S. Turnê de E. V. Guéltser. In: MARQUES, P. N. O Vygótski incógnito: Escritos sobre arte (1915-1926). 2015. Tese (Doutorado em Literatura e Cultura Russa) - FFLCH - Universidade de São Paulo, São Paulo, 2015a, p. 264-267.

VIGOTSKI, L. S. Turnês de Utiôssov e Foregger. In: MARQUES, P. N. O Vygótski incógnito: Escritos sobre arte (1915-1926). 2015. Tese (Doutorado em Literatura e Cultura Russa) - FFLCH - Universidade de São Paulo, São Paulo, 2015b, p. 271-274. 
VIGOTSKI, L. S. O filhote de águia - O discípulo do diabo. In: MARQUES, P. N. O Vygótski incógnito: Escritos sobre arte (1915-1926). 2015. Tese (Doutorado em Literatura e Cultura Russa) - FFLCH Universidade de São Paulo, São Paulo, 2015c, p. 236-239.

VIGOTSKI, L. S. A arte gráfica de Bykhóvski. In: MARQUES, P. N. O Vygótski incógnito: Escritos sobre arte (1915-1926). 2015. Tese (Doutorado em Literatura e Cultura Russa) - FFLCH - Universidade de São Paulo, São Paulo, 2015d, p. 281-287.

VIGOTSKI, L. S. Krasnyi Fakel. Polnoe sobránie sotchiniénii: dramaturgia i teatr. Tom 1. Moscow: Lev, 2015e.

VIGOTSKI, L. S.; LEONTIEV, A. N. Prefácio ao livro de A. N. Leontiev, “O desenvolvimento da memória”. Cad. Cedes, v. 40, n. 111, 2020. https://doi.org/10.1590/CC225970

ZAVERSHNEVA, E. The way to freedom: Vygotsky in 1932. In: YASNITSKY, A.; VAN DER VEER, R. Revisionist Revolution in Vygotsky Studies. Nova York: Routledge, 2016.

Recebido: 01 Jul 2019

Aceito: 30 Nov 2019

Comitê Editorial do Cedes/Coordenação deste número:

Silvia Cordeiro Nassif e Maria Silvia Pinto de Moura Librandi da Rocha 